\title{
The Role of the Code Blue Team Nurses in Managing Cardiac Arrest Patients in Hospitals: A Systematic Review
}

\author{
Wawan Joko Apriyanto ${ }^{1}$, Indah Winarni ${ }^{2}$, Setyoadi ${ }^{3}$ \\ ${ }^{1}$ Master Program of Nursing, Faculty of Medicine of Brawijaya University, Malang, \\ Indonesia \\ ${ }^{2,3}$ Departemen of Nursing, Faculty of Medicine of Brawijaya University, Malang, \\ Indonesia \\ Email: waone.joke@gmail.com
}

\begin{abstract}
The purpose of this study is to find out how the role of the code blue team nurses in handling patients with cardiac arrest in the hospital. A systematic review has been carried out through several stages, namely making questions, identifying, eligibility, selecting article inclusions, screening, and appraisal. The selection process is listed in the review systematic framework and 6 article articles are obtained. The articles are summarized and assessed by JBI (Joanna Briggs Institute). A systematic review show different results, as follows: majority of nurses felt confident and competent during the call, and that nontechnical skills were performed more frequently than technical skills. These outcomes support the continued use of ongoing simulation training to further improve team performance, maintain member confidence, and assure quality patient care. Role nurse is increase teamwork and interprofessional team training, increased knowledge and skills, communication, increased confidence and comfort, simulation experience, debriefing and reflective learning. There is no significant difference in survival from cardiac arrest when a standardized "Code Blue Team" is utilized, regardless of the time of day or week. Comparison of MET (Medical Emergency Team) and code blue calls before and after implementation of the ADDS (Acute Deterioration Detection System): there was a significant increase in activations proportional to admissions found in the year after the implementation. The role of a code blue team nurse includes non-medical: communication skills, leadership skills, team interaction skills, and task coordination skills. Medical skills: chest compression skills and early defibrillation skills.
\end{abstract}

Keywords: Nurse's Role, Cardiac Arrest, Code Blue Team.

\section{A. INTRODUCTION}

Cardiac arrest and respiratory arrest are events that often occur in hospitals that can be caused by chronic terminal illness or acute pain that results in sudden death. Hypoxemia due to severe respiratory insufficiency, overdosing of drugs either intentionally or unintentionally, or neurological disorders can also result in cardiac arrest and unexpected breathing stops ${ }^{8}$. Heart attacks are still a significant cause in hospitals that cause morbidity and mortality worldwide. Although the progress of therapy has been significant since the application of closed heart massage in 1960, the survival rate is in the range of $17-32 \%$. Many factors have been found to influence survival after a heart attack in a hospital, including the patient's age, comorbidity, primary dysrhythmia, duration of CPR, and knowing an early 
heart attack. Most of these factors describe pre-existing conditions that cannot be easily controlled by the resuscitation team at the hospital ${ }^{15}$.

Heart attacks in hospitals occur in more than 290,000 adults each year in the United States. Cohort data from the United States show that the average age of patients with cardiac arrest in hospital is 66 years, 58\% are male, and most often heart rhythm disorders, $81 \%$ are non shockable namely asystol or PEA (Pulseless Electrical Activity). The most common cause of cardiac arrest is the heart $(50 \%-60 \%)$, followed by respiratory insufficiency (15\%-40\%). Efforts to prevent cardiac arrest in hospitals require a system to identify deteriorating patients and appropriate response actions, for example the rapid response team. Key elements of treatment during cardiac arrest including chest compression, ventilation, early defibrillation can be applied, and immediate attention to potentially reversible causes, such as hyperkalemia or hypoxia ${ }^{1}$.

Hospital emergency codes are used throughout the world to remind staff about various emergency situations in hospitals. The use of the code is intended to convey important information quickly with minimal misunderstanding to hospital staff, while preventing stress or panic among hospital visitors. Code blue is generally used for patients who need resuscitation or need immediate medical attention, most often due to cardiac arrest or breathing that is common in hospitals, delayed treatment is associated with lower survival rates ${ }^{13}$. Each hospital, as part of the disaster plan, establishes policies to determine which units provide personnel for the coverage of the blue code. In theory, every medical professional can respond to the code, but in practice the team structure is limited to those who have advanced cardiac life support or other equivalent resuscitation training. The rapid response team leader or doctor is responsible for directing resuscitation efforts and running the code ${ }^{7}$.

Most victims of cardiac arrest initially experience ventricular fibrillation. Chest compressions can maintain optimal cardiac output levels in a few moments but cannot convert life-threatening heart rhythms. Defibrillation is the only definitive action. The time interval from collapse to defibrillation is a major determinant in the survival of victims with cardiac arrest. Automatic external defibrillator (AED) is very useful for administering defibrillation that does not require helper or operator to interpret rhythm. AED machine will determine whether the rhythm can be given an electric shock (shockable) or not. Helpers are considered to be familiar with Basic Life Support (BLS) principles and quality compression techniques. Every nurse must have a BLS certification.

Coordination of health care providers at various levels of experience and training is very important for the survival of patients who have had a heart attack in the hospital. Once the code blue team arrives, a rapid exchange of information is important, along with immediate implementation of CPR. Synchronizing assigned tasks and coordination tasks are the challenges needed for patient safety. The code blue team works best with team leaders and members who know their roles, communicate, and work effectively with each other ${ }^{3}$. Effective communication is 
very important for teams that work in crisis situations. Good teamwork depends on everyone who is in the same place. Communication ensures that everyone knows what is happening, what needs to be done and what has been done ${ }^{2}$.

\section{B. METHOD}

The preparation of this review goes through several stages namely making research questions according to PICO rules, and then conducting a literature review using diagrams. The diagram includes identification, eligibility, screening and determination of articles that have been included. In the final stage, the review is carried out systematically using tables and calculates the JBI value in each article. The steps are as follows:

\section{Identify relevant journal articles from titles and abstracts}

Journal article identification is done by searching journal articles in two databases, the database used by the author is Proquest and Google Scholar. Before conducting a search, the authors chose the settings on each database search page, namely: international published articles between the years 2010-2019, the type of reference is the article, the language used is English and Indonesian. After completing the search settings then search for articles using keywords. The keywords used by the authors in this systematic review are 4 in each database, namely Role, Nurse, code blue teams, cardiac arrest and in hospital. From these keywords, it is hoped that a systematic review will be conducted to answer the researcher's questions. Then after searching on each keyword, the author combines/combines those keywords with conjunctions "and". At the Identification stage, the number of articles obtained in the Proquest database is 201 articles, in the Google Scholar database there are 2 articles.

\section{Screening and Eligibility}

At this stage the fulfillment of the requirements is an adjustment based on the appropriateness of the title and abstract of the article, At the Eligibility stage the remaining articles in the Proquest database are 10 articles, and the Google Scholar database is 6 articles.

\section{Selection of Articles that Have Been Included}

The selection of articles that have been included is a selection process based on existing inclusion and exclusion criteria. Inclusion and exclusion criteria have been determined by the author. These inclusion criteria include: the role and function of nurses working in hospitals, the role of code blue team nurses who handle patients with cardiac arrest, articles or journals in English and Indonesian. Other inclusion criteria are articles with full text. Meanwhile, the exclusion criteria are as follows: the role and function of nurses who work outside the hospital (out of hospital), articles or journals in the form of systematic reviews, articles that only display only abstracts, without being accompanied by full text, and articles that are 
difficult to download because it's paid. The results at the adjustment stage based on inclusion and exclusion criteria were 4 articles in the Proquest database and 2 articles in the Google Scholar data base.

\section{Screening and Appraisal}

Screening is the stage to see if there are similar articles between the two existing databases. Of the total articles that have gone through the previous stage of 6 articles, there are no similar articles (no duplicates), so at the screening stage the number of articles remaining is 6 articles. 


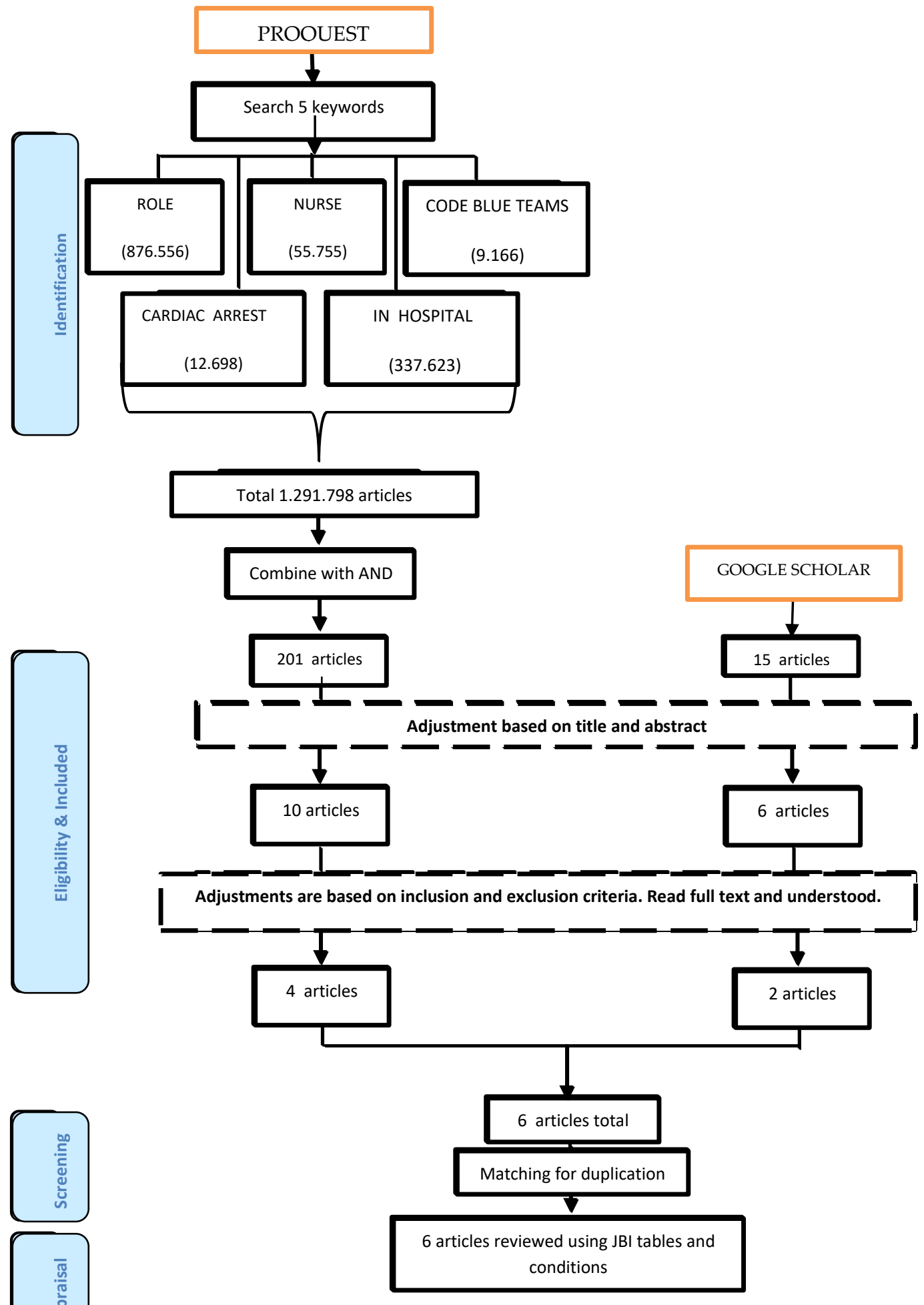

Figure 1 Prisma Flow Chart Diagram

The Appraisal Phase is to assess 6 existing articles. At this stage the author summarizes the article and evaluates the JBI (Joanna Brigg Institution checklist) for each article according to the method of the article. The assessment results are attached in table 1. 
Table 1 Journal Articles Discussed

\begin{tabular}{|c|c|c|c|c|c|c|c|}
\hline $\begin{array}{c}\text { Author } \\
\text { (Year) }\end{array}$ & Title & $\begin{array}{c}\text { Level } \\
\text { (JBI) }\end{array}$ & Objectives & Method & Sample & Data Analysis & Research Result \\
\hline $\begin{array}{l}\text { Topple, } \\
\text { Michelle; Rya } \\
\text { n, } \\
\text { Brooke; Baldw } \\
\text { in, } \\
\text { Ian; McKay, } \\
\text { Richard; Blyth } \\
\text { e, Damien; et } \\
\text { al. } \\
\text { (2016) }\end{array}$ & $\begin{array}{l}\text { Tasks } \\
\text { completed by } \\
\text { nursing } \\
\text { members of a } \\
\text { teaching } \\
\text { hospital } \\
\text { Medical } \\
\text { Emergency } \\
\text { Team }\end{array}$ & 3.e & $\begin{array}{l}\text { To asses task } \\
\text { completed by } \\
\text { intensive care } \\
\text { medical } \\
\text { emergency } \\
\text { teams nurses }\end{array}$ & $\begin{array}{l}\text { a prospective } \\
\text { observational } \\
\text { study }\end{array}$ & $\begin{array}{l}\text { a total of } 400 \\
\text { MET } \\
\text { (Medical } \\
\text { Emergency } \\
\text { Teams) calls } \\
\text { were } \\
\text { identified. }\end{array}$ & $\begin{array}{l}\text { Inferential statistics comparing } \\
\text { continuous data was conducted } \\
\text { using the Mann-Whitney U test } \\
\text { for group-group comparisons, and } \\
\text { comparison of categorical data } \\
\text { and proportions was conducted } \\
\text { using the chi-sq. test, or Fishers } \\
\text { exact test as appropriate. In all } \\
\text { statistical tests, a two sided p- } \\
\text { value of }<0.05 \text { was taken to } \\
\text { indicate statistical significance. }\end{array}$ & $\begin{array}{l}\text { Overall, that the vast } \\
\text { majority of nurses felt confident and } \\
\text { competent during the call, and that } \\
\text { non-technical skills were performed } \\
\text { more frequently than technical } \\
\text { skills. }\end{array}$ \\
\hline $\begin{array}{lr}\text { Cynthia } & \text { R. } \\
\text { Prince, RN, } \\
\text { CEN; } \\
\text { Elizabeth J. } \\
\text { Hines, BA; Po- } \\
\text { Huang Chyou, } \\
\text { PhD; and } \\
\text { David J. } \\
\text { Heegeman, } \\
\text { MD } \\
\\
(2014)\end{array}$ & $\begin{array}{l}\text { Finding the } \\
\text { Key to a } \\
\text { Better Code: } \\
\text { Code Team } \\
\text { Restructure to } \\
\text { Improve } \\
\text { Performance } \\
\text { and } \\
\text { Outcomes }\end{array}$ & $4 . b$ & $\begin{array}{l}\text { To improve the } \\
\text { overall } \\
\text { performance of } \\
\text { our hospital's } \\
\text { code team, we } \\
\text { implemented an } \\
\text { evidence-based } \\
\text { quality } \\
\text { improvement } \\
\text { restructuring } \\
\text { plan. }\end{array}$ & $\begin{array}{l}\text { Descriptive } \\
\text { statistics, } \\
\text { including } \\
\text { frequency and } \\
\text { percentage, } \\
\text { were collected } \\
\text { into separate } \\
\text { tables based on } \\
\text { the } \\
\text { questionnaire } \\
\text { results for years } \\
2009 \text { and } 2011 .\end{array}$ & $\begin{array}{l}\text { In the study } \\
\text { Not } \\
\text { explained } \\
\text { with } \\
\text { certainty the } \\
\text { number of } \\
\text { samples }\end{array}$ & $\begin{array}{l}\text { Data is analyzed in terms of } \\
\text { frequency and percentage }\end{array}$ & $\begin{array}{l}\text { These result in a code team with } \\
\text { improved confidence in their role } \\
\text { specific skills, clarity in their role } \\
\text { positions, and team leadership, as } \\
\text { well as a decrease in the time-to- } \\
\text { defibrillation. These outcomes also } \\
\text { support the continued use of } \\
\text { ongoing simulation training to } \\
\text { further improve team performance, } \\
\text { maintain member confidence, and } \\
\text { assure quality patient care. }\end{array}$ \\
\hline $\begin{array}{l}\text { Sharon C. } \\
\text { O'Donoghue, } \\
\text { Susan } \\
\text { DeSanto- } \\
\text { Madeya, } \\
\text { Natalie Fealy, } \\
\text { Christine R. } \\
\text { Saba, Stacey } \\
\text { Smith, Allison } \\
\text { T. McHugh }\end{array}$ & $\begin{array}{l}\text { Nurses' } \\
\text { Perceptions of } \\
\text { Role, Team } \\
\text { Performance, } \\
\text { and } \\
\text { Education } \\
\text { Regarding } \\
\text { Resuscitation } \\
\text { in the Adult } \\
\text { Medical- }\end{array}$ & 2 & $\begin{array}{l}\text { The purpose of } \\
\text { this study was } \\
\text { to explore } \\
\text { nurses' } \\
\text { perception of } \\
\text { their roles, team } \\
\text { performance, } \\
\text { and educational } \\
\text { needs during } \\
\text { resuscita-tion }\end{array}$ & $\begin{array}{l}\text { The mixed } \\
\text { method. } \\
\text { a qualitative } \\
\text { methodology to } \\
\text { analyze } \\
\text { narrative data } \\
\text { from open- } \\
\text { ended survey } \\
\text { questions and } \\
\text { quantitative }\end{array}$ & $\begin{array}{l}\text { A total of } \\
360 \text { nurses } \\
\text { participated } \\
\text { in the } \\
\text { training } \\
\text { program }\end{array}$ & $\begin{array}{l}\text { For the qualitative data, } \\
\text { investigators with diverse } \\
\text { backgrounds (registered nurses, } \\
\text { PhD educators, and a physician) } \\
\text { initially con-ducted independent } \\
\text { content analyses, where broad } \\
\text { themes were generated on the } \\
\text { basis of an examination of the } \\
\text { narrative data. Refine-ment of } \\
\text { themes was accomplished }\end{array}$ & $\begin{array}{l}\text { Results of the content analysis } \\
\text { generated } 10 \text { main themes (with the } \\
\text { number of exemplars associated } \\
\text { with each theme and percent): } \\
\text { opportunity for hands on practice } \\
\text { and experience (39, 18.4\%), } \\
\text { increased awareness and } \\
\text { preparedness (32, 15.1\%), role } \\
\text { clarity (27, } 12.7 \%) \text {, teamwork and } \\
\text { interprofessional team training (27, }\end{array}$ \\
\hline
\end{tabular}




\begin{tabular}{|c|c|c|c|c|c|c|}
\hline (2015) & $\begin{array}{l}\text { Surgical } \\
\text { Patient }\end{array}$ & $\begin{array}{l}\text { using an } \\
\text { electronic } \\
\text { survey. Findings } \\
\text { provide } \\
\text { direction for } \\
\text { clinical practice, } \\
\text { nursing } \\
\text { education, and } \\
\text { future research } \\
\text { to improve } \\
\text { resus-citation } \\
\text { care. }\end{array}$ & $\begin{array}{l}\text { methodology to } \\
\text { analyze Likert- } \\
\text { response items } \\
\text { as described } \\
\text { later. }\end{array}$ & & $\begin{array}{l}\text { through an iterative process } \\
\text { involving face-to-face meet-ings, } \\
\text { reexamination of data, coding, } \\
\text { and fur-ther refinement of themes } \\
\text { until consensus was reached. } \\
\text { The quantitative data were } \\
\text { analyzed with descriptive } \\
\text { statistics. }\end{array}$ & $\begin{array}{l}12.7 \%) \text {, increased knowledge and } \\
\text { skills (21, } 9.9 \%) \text {, communication (16, } \\
7.8 \%) \text {, increased confidence and } \\
\text { comfort }(15,7.1 \%) \text {, simulation } \\
\text { experience }(14,6.6 \%) \text {, debriefing } \\
\text { and reflective learning }(13,6.1 \%) \text {, } \\
\text { and patient outcomes }(5,24 \%) \text {. }\end{array}$ \\
\hline $\begin{array}{l}\text { Sultana A. } \\
\text { Qureshi, MD, } \\
\text { Terence } \\
\text { Ahern, BA, } \\
\text { Ryan O'Shea, } \\
\text { BA, Lorien } \\
\text { Hatch, MA, } \\
\text { and Sean O. } \\
\text { Henderson, } \\
\text { MD } \\
(2012)\end{array}$ & $\begin{array}{l}\text { A Standarized } \\
\text { Code Blue } \\
\text { Team } \\
\text { Eliminates } \\
\text { Variable } \\
\text { Survival From } \\
\text { IN-Hospital } \\
\text { Cardiac } \\
\text { Arrest }\end{array}$ & $\begin{array}{l}\text { To assess if time } \\
\text { of day or week } \\
\text { affects survival } \\
\text { from in-hospital } \\
\text { cardiac arrest } \\
\text { when a trained, } \\
\text { consistent, } \\
\text { emergency } \\
\text { physician-led } \\
\text { CBT is } \\
\text { implemented }\end{array}$ & $\begin{array}{l}\text { This study was } \\
\text { an analysis of } \\
\text { prospectively } \\
\text { collected data of } \\
\text { all cardiac } \\
\text { arrest, or "Code } \\
\text { Blue," events in } \\
\text { one hospital } \\
\text { from February } \\
2000 \text { to February } \\
2008 .\end{array}$ & $\begin{array}{l}\text { A total of } \\
1692 \text { cardiac } \\
\text { arrests }\end{array}$ & $\begin{array}{l}\text { Data were collected prospectively } \\
\text { from a standardized patient } \\
\text { reporting form, and analysis was } \\
\text { performed using Stata/SE } 10 \\
\text { software (StataCorp LP, College } \\
\text { Station, TX). The Yates-corrected } \\
\text { chi-squared statistic was used to } \\
\text { measure significance in com- } \\
\text { paring survival and non-survival } \\
\text { groups. Odds ratios were also } \\
\text { calculated as a clinical summary } \\
\text { statistic of risk. }\end{array}$ & $\begin{array}{l}\text { There is no significant difference in } \\
\text { survival from cardiac arrest when a } \\
\text { standardized "Code Blue Team" is } \\
\text { utilized, regardless of the time of } \\
\text { day or week. }\end{array}$ \\
\hline $\begin{array}{lr}\text { Carleen } & \text { R. } \\
\text { Spitzer, } & \\
\text { Kimberly } & \\
\text { Evans, } & \text { Jeri } \\
\text { Buehler, } & \\
\text { Naeem A. } & \text { Ali, } \\
\text { Beth } & \text { Y. } \\
\text { Besecker } & \\
(2019) & \end{array}$ & $\begin{array}{l}\text { Code blue } 4 . b \\
\text { pit crew } \\
\text { model: A } \\
\text { novel } \\
\text { approach to } \\
\text { in-hospital } \\
\text { cardiac } \\
\text { arrest } \\
\text { resuscitation }\end{array}$ & $\begin{array}{l}\text { To assess the } \\
\text { effect of our } \\
\text { model, we } \\
\text { reviewed pre- } \\
\text { and post-pit } \\
\text { crew } \\
\text { implementation } \\
\text { data from five } \\
\text { sources: } \\
\text { defibrillator } \\
\text { downloads, a } \\
\text { centralized }\end{array}$ & $\begin{array}{l}\text { Retrospective } \\
\text { method. } \\
\text { All patients who } \\
\text { had a true } \\
\text { cardiopulmonar } \\
\text { y arrest (CPA) at } \\
\text { the main } \\
\text { campus of our } \\
\text { tertiary care, } \\
\text { academic } \\
\text { medical center } \\
\text { were included }\end{array}$ & $\begin{array}{l}159 \\
\text { cardiopulmo } \\
\text { nary arrest } \\
\text { events }\end{array}$ & $\begin{array}{l}\text { Data with continuous variables } \\
\text { and normal distribution was } \\
\text { analyzed using a standard two- } \\
\text { sample t-test test. If data were not } \\
\text { normally distributed, a Mann- } \\
\text { Whitney U test was performed. } \\
\text { For yes/ no categorical data either } \\
\text { a Z-test for difference between } \\
\text { proportions or Chi-square test } \\
\text { were used. Two-tailed analysis } \\
\text { was used unless otherwise noted. }\end{array}$ & $\begin{array}{l}\text { There were exactly } 159 \\
\text { cardiopulmonary arrest events at } \\
\text { medical center in both the pre- } \\
\text { intervention (April } 2013 \text { - December } \\
\text { 2013) and post-intervention } \\
\text { (October } 2014 \text { - June 2015) time } \\
\text { periods. Each time frame included } \\
\text { three quarters of code events with a } \\
\text { nine month gap during the } \\
\text { intervention period. }\end{array}$ \\
\hline
\end{tabular}




\begin{tabular}{|c|c|c|c|c|c|c|c|}
\hline & & & $\begin{array}{l}\text { hospital } \\
\text { database, mock } \\
\text { codes, expert- } \\
\text { led debriefings, } \\
\text { and confidential } \\
\text { surveys. }\end{array}$ & $\begin{array}{l}\text { in this quality } \\
\text { improvement } \\
\text { project. Data } \\
\text { were reviewed } \\
\text { for all events } \\
\text { pre-intervention } \\
\text { (April 2013- } \\
\text { December 2013) } \\
\text { and post- } \\
\text { intervention } \\
\text { (October 2014- } \\
\text { June 2015). }\end{array}$ & & & \\
\hline $\begin{array}{l}\text { Karen } \\
\text { Missen, } \\
\text { Joanne. E. } \\
\text { Porter, } \\
\text { Anita } \\
\text { Raymond, } \\
\text { Kerry de } \\
\text { Vent, Jo- } \\
\text { Ann } \\
\text { Larkins } \\
\text { (2017) }\end{array}$ & $\begin{array}{l}\text { Adult } \\
\text { Deterioration } \\
\text { Detection } \\
\text { System } \\
\text { (ADDS): An } \\
\text { evaluation of } \\
\text { the impact on } \\
\text { MET and } \\
\text { Code blue } \\
\text { activations in } \\
\text { a regional } \\
\text { healthcare } \\
\text { service }\end{array}$ & & $\begin{array}{l}\text { To evaluate the } \\
\text { impact of Acute } \\
\text { Deterioration } \\
\text { Detection } \\
\text { System (ADDS) } \\
\text { charts } \\
\text { introduced to a } \\
\text { regional } \\
\text { healthcare } \\
\text { service. }\end{array}$ & $\begin{array}{l}\text { A retrospective } \\
\text { study of all } \\
\text { Code Blue and } \\
\text { MET activations } \\
\text { was undertaken } \\
\text { at a regional } \\
\text { hospital, pre } \\
\text { and post the } \\
\text { introduction of } \\
\text { ADDS charts in } \\
\text { a two year } \\
\text { period, June } \\
2012 \text { to June } \\
2014 .\end{array}$ & $\begin{array}{l}191 \text { patient } \\
\text { records pre } \\
\text { implementat } \\
\text { ion and } 399 \\
\text { recorded } \\
\text { after the } \\
\text { implementat } \\
\text { ion of the } \\
\text { ADDS chart. }\end{array}$ & $\begin{array}{l}\text { To compare two or more } \\
\text { independent samples, the Chi- } \\
\text { square }\left({ }^{2}\right) \text { test of Contingencies } \\
\text { was used which assessed whether } \\
\text { the variables were related and } \\
\text { whether the relationship was } \\
\text { statisti-cally significant. The Chi- } \\
\text { square }\left({ }^{2}\right) \text { goodness of fit (one } \\
\text { sample Chi-square) was used to } \\
\text { determine whether the observed } \\
\text { numbers differed from expected } \\
\text { frequencies in a single category. }\end{array}$ & $\begin{array}{l}\text { Comparison of MET and Code Blue } \\
\text { calls before and after imple- } \\
\text { mentation of the ADDS: } \\
\text { When comparing the number of } \\
\text { MET call activations per } 1000 \\
\text { patients before and after the } \\
\text { implementation of the ADDS chart, } \\
\text { there was a significant increase (p < } \\
0.01 \text { ) in activations proportional to } \\
\text { admissions found in the year after } \\
\text { the implementation, summarizes } \\
\text { the number of Code Blue and MET } \\
\text { call activations proportional to } \\
\text { admissions before and after the } \\
\text { imple-mentation of the ADDS chart. }\end{array}$ \\
\hline
\end{tabular}




\section{RESULTS AND DISCUSSION}

Although the science of cardiac pulmonary resuscitation has progressed over the past several decades, the likelihood of heart attack patients who can survive neurologically remains low. When a heart attack in the hospital occurs, the survival of the patient depends on the action of cardiac pulmonary resuscitation immediately, because every minute of delay from the time of cardiac arrest for initiation of cardiac resuscitation of the paralyzed decreased $10 \%$ chance of survival. Resuscitation in patients with cardiac arrest requires immediate and coordinated efforts from several service providers ${ }^{4}$. The occurrence of cardiac arrest in the hospital needs special attention because it is related to the causes of high mortality, also related to the early detection system of the decline in the patient's condition and the hospital's response in the face of cardiac arrest in patients being treated ${ }^{18}$. A successful resuscitation requires early recognition of cardiopulmonary arrest and early intervention by skilled providers. Despite the development and widespread implementation of CPR and advanced life support in the last 40 years, in hospital cardiac arrest patients continue to have poorer than expected outcomes ${ }^{15}$.

Hospital Emergency Codes are used in hospitals worldwide to alert staff to various emergencies. The use of codes is intended to convey essential information quickly and with minimal misunderstanding to staff, while preventing stress and panic among visitors to the hospital. "Code Blue" is generally used to indicate a patient requiring resuscitation or in need of immediate medical attention, most often as the result of a respiratory arrest or cardiac arrest ${ }^{12}$. Quick Reaction Team as a health staff specially formed to handle emergency patients is demanded to be able to provide emergency assistance to emergency patients quickly and appropriately. Quick Reaction Team is a team in charge of providing immediate relief to patients with emergency care before and during cardiac arrest. Quick Reaction Team is part of the Code Blue System, which is an international sign code used in hospitals that indicates a patient who is having a heart attack or is experiencing a situation of acute respiratory failure and other emergency emergencies relating to the patient's life ${ }^{20}$.

Team performance depends in part on identification and delegation of team roles and tasks. A lack of clarity exists within the literature on code team composition and team members' specific roles during a resuscitation. Role ambiguity and confusion for code team members often exists, possibly creating poor communication and ineffective teamwork that lead to poor patient outcomes. A first step in optimizing team performance is understanding the prevalence and nature of role ambiguity among members of the code team ${ }^{10}$. Emergency Nurse Practitioners (ENPs) are specialized licensed practitioners, who possess the necessary clinical competencies to provide optimal care to patients in ambulatory, urgent, and emergent care settings. ENPs demonstrate competencies by applying standardized care guidelines in their clinical practice. Other ways of continuing competencies include participation in maintaining continuing education, quality improvement processes and peer reviews including the systematic periodic review of records 
and treatment plans while maintaining specialty and population focused certification in compliance with current laws and regulations ${ }^{9}$.

Resuscitation is a complex process which requires coordination of team members. First, strong team leaders are needed to organize the group, delegate tasks, and monitor the performance of team members. Effective teamwork reduces unwanted errors caused by failure to communicate clearly ${ }^{3}$.

The keys to a better code team are organization, clearly identified roles, and frequent team practice in the form of mock codes. These result in a code team with improved confidence in their role specific skills, clarity in their role positions, and team leadership, as well as a decrease in the time-to-defibrillation. These outcomes also support the continued use of ongoing simulation training to further improve team performance, maintain member confidence, and assure quality patient care. Therefore, a restructured code team is beneficial to many, including the team members, the medical institution, and patients ${ }^{14}$.

Non medical skills, including communication, leadership, team interaction, and task coordination, play as much of a role during a code response as medical skills such as chest compressions and early defibrillation. If any of these skill variables is lacking, possibly due to the fact that resuscitations may not be a frequent occurrence for all team members, and stress among staff during these events is high, the effectiveness of a code team's performance could be hindered ${ }^{14}$. Findings provide important information on the tasks completed by Medical Emergency Team nurses and will guide future training. Non-technical skills are important skills for nurses to possess for conduct in a Medical Emergency Team call. Nurses who participate in Medical Emergency Teams calls need to be skilled in communication and clinical assessment ${ }^{19}$.

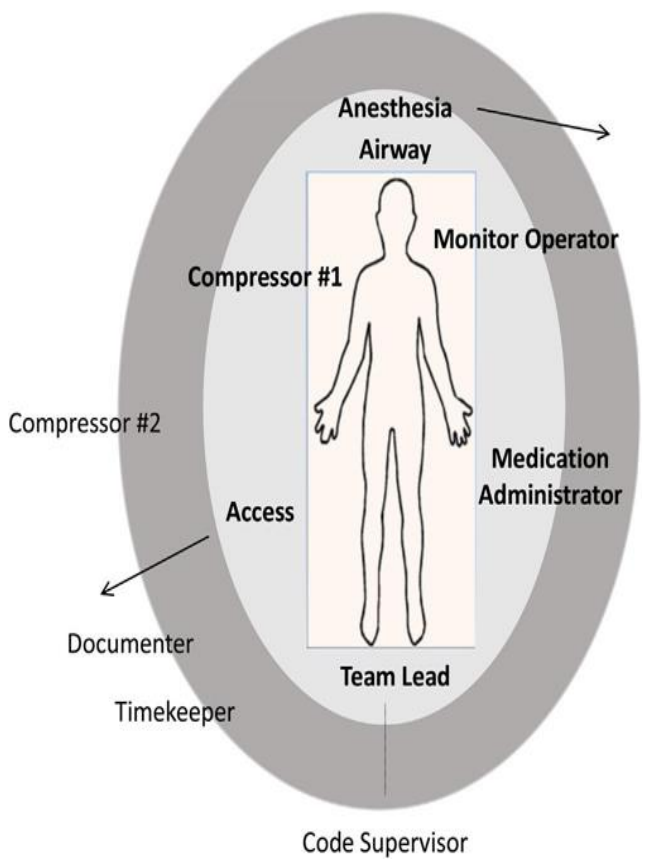

Figure 2 Code Blue Team Position during Resuscitation 
The code blue team consists of: leader, airway/anesthesia (ventilator), compressor, sirkulator, monitor /defibrilator, medication administrator and dokumenter. Role of Leader code blue team is Leading code team as per ACLS algorithm, assess "Hs \& Ts" regarding cause for code event. Role of compressor \#1 is completing chest compression. Role of compressor \#2 is switch off/on with compressor \#1 every 2 minutes cycle. Role of airway manager /anesthesia is establishing advanced airway; bag patient at appropriate rate depending on if advanced airway is present or not. Role of medication administrator is administrating medications, read-back all medications. Role of monitor /defibrillator operator is operating defibrillator including charging/shocking as appropriate, aid with rhythm interpretation. Role of documenter is documentating code events in the EMR $^{17}$.

Roles and responsibilities of the resuscitation team are:

1. Team leader has a role and responsibility in directing assessments and interventions, observing team members when carrying out assigned roles, ensuring repeated closed communication, asking team members for input, teaching and strengthening the efforts made by team members.

2. Airway manager has the role and responsibility of maintaining airway patency, continuously monitoring the respiratory status and ventilation of the patient, providing adequate ventilation with bag-valve mask or further airway aids, requesting arterial blood gas examination, monitoring the effectiveness of chest compressions and reminding the compressor to alternately if exhausted, participating in closed communication.

3. Chest compressor has the role and responsibility of conducting RJP properly and correctly and uninterruptedly, realizes if tired and expresses a desire to alternate with other team members, participates in closed communication.

4. Nurse treatment has the role and responsibility of installing and maintaining IV access, the defibrillator operator, monitors the pulse during compression, gives IV medication, examines vital signs if needed, participates in closed communication.

5. Recorder has the role and responsibility of documenting all resuscitation steps, informing team members regarding medications and interventions that have been carried out, giving information about the patient's medical history to the team, participating in closed communication ${ }^{8}$.

Code blue simulation is very necessary to improve nurse performance during the first 5 minutes of patient crisis. In the simulation code blue team nurses will be taught several things, namely: identify the declining patient health status requiring urgent intervention and notification of the emergency response teams, execute the proper first responder procedure per hospital policy, perform the appropriate interventions based upon patient assessment, demonstrate the proper techniques of basic cardiac life support including 1 minute to CPR and 3 minutes to defibrillation, demonstrate clear effective hand-off communication to the arriving health team members ${ }^{5}$. There is evidence to suggest that high-fidelity simulation is useful for 
evaluating clinical processes, such as CPR performance as well as team interactions during simulated codes ${ }^{4}$. Code blue simulation is an annual, mandatory skill for all nurses at our facility. The low-stress simulation provides opportunities for learning and reinforcing critical BLS skills that could positively impact patient outcomes. A briefing is followed by a blue simulation code. The educator unit asks the nursing team to identify what is good during the simulation. Nurses complimented their team members for actions such as responsiveness to calls for help, initiation of compression, carrying accident baskets to the room, AED pad placement, and using safe sequences to provide shock ${ }^{16}$. Staff development educators play a significant role in the design and implementation of teaching strategies to ensure knowledge and skill acquisition of healthcare providers, teamwork, and competency in CPR. An ongoing curriculum addressing code team roles and responsibilities, team leadership education, and multi-disciplinary mock codes is critical to ensure a proficient staff response to a code ${ }^{6}$.

To improve patient outcomes, it is very important that the blue code team show effective and communication team work. Clear roles and responsibilities must be defined to promote the organization during the blue code. Communication failure is also touted as the cause of bad events. An imitation code study in 2015 found that it was not clear which respondents led the code team and the team did not have effective communication. As a result, code team members are confused about who should lead. In addition, code team respondents rarely introduce themselves when they arrive at the scene or clarify their roles and responsibilities ${ }^{3}$.

\section{CONCLUSION}

Cardiac arrest patients in the hospital need immediate treatment from the code blue team. A delay every minute in the management of cardiac arrest patients will cause the patient to experience a $10 \%$ reduction in survival. Code blue team nurses must practice knowledge and skills in dealing with cardiac arrest patients so that they can play a role in the code blue team well. By frequently performing simulations of cardiac arrest in hospitals, nurses will be able to improve their knowledge and skills consisting of non medical skills and medical skills. Non medical skills include: communication skills, leadership skills, team interaction skills, and task coordination skills. While medical skills include: chest compression skills and early defibrillation skills. The keys to a better code team are organization, clearly identified roles, and frequent team practice in the form of mock codes. These result in a code team with improved confidence in their role specific skills, clarity in their role positions, and team leadership, as well as a decrease in the time-todefibrillation. These outcomes also support the continued use of ongoing simulation training to further improve team performance, maintain member confidence, and assure quality patient care. The roles and responsibilities of each team member must be clear. The team leader must establish clear roles and responsibilities for each team member. Team members must communicate well if they are able to manage additional tasks. 


\section{REFERENCES}

1. Andersen, L. W., Holmberg, M. J., Berg, K. M., Donnino, M. W., \& Granfeldt, A. (2019). In-hospital cardiac arrest: a review. Jama, 321(12), 1200-1210. https://doi.org/10.1001/jama.2019.1696

2. College, M. (2011). Code Blue team: Roles and Function. Retrieved from https://www.montgomerycollege.edu/ documents/academics_/departments Lnursing-tpss/code-blue-team-roles-and-function.pdf

3. Campo, T. M., Carman, M. J., Evans, D., Hoyt, K. S., Kincaid, K., Ramirez, E. G., ... \& Weltge, A. (2016). Standards of practice for emergency nurse practitioners. Advanced Emergency Nursing Journal, 38(4), 255-258.

4. Chu, R. (2019). Code blue: Effective resuscitation teams. Nursing made Incredibly Easy, 17(5), 13-16.

5. Clarke, S., Apesoa-Varano, E. C., \& Barton, J. (2016). Code Blue: methodology for a qualitative study of teamwork during simulated cardiac arrest. BMJ open, 6(1). https://doi.org/10.1136/bmjopen-2015-009259

6. Delac, K., Blazier, D., Daniel, L., \& Donamarie, N. (2013). Five alive: using mock code simulation to improve responder performance during the first 5 minutes of a code. Critical Care Nursing Quarterly, 36(2), 244-250. https://doi.org/10.1097/CNQ.0b013e3182846f1a

7. Dorney, P. (2011). Code blue: Chaos or control, an educational initiative. Journal for Nurses in Professional Development, 27(5), 242-244. https://doi.org/10.1097/NND.0b013e31822d6ee4

8. Eroglu, S. E., Onur, O., Urgan, O., Denizbasi, A., \& Akoglu, H. (2014). Blue code: Is it a real emergency?. World journal of emergency medicine, 5(1), 20-23.

9. Hammond, B. B., \& Zimmermmann, P. G. (2015). Sheehys Manual of Emergency Care. Singapore.

10. Missen, K., Porter, J. E., Raymond, A., de Vent, K., \& Larkins, J. A. (2018). Adult Deterioration Detection System (ADDS): An evaluation of the impact on MET and Code blue activations in a regional healthcare service. Collegian, 25(2), 157161. https://doi.org/10.1016/j.colegn.2017.05.002

11. Patil, V. C., Shah, J. N., Jedge, P. P., \& Patil, S. V. (2019). Review of code blue system and audit. International Journal of Research in Medical Sciences, 7(5), 1809.

12. Pattnaik, S. K., Ray, B., Nayak, J., Prusty, A., \& Sinha, S. (2015). Code blue protocol: observation and analysis of results over last 3 years in a new tertiary care hospital. Intensive care medicine experimental, 3(1), 1-1. https://doi.org/10.1186/2197-425X-3-S1-A205

13. Prince, C. R., Hines, E. J., Chyou, P. H., \& Heegeman, D. J. (2014). Finding the key to a better code: code team restructure to improve performance and $\begin{array}{llll}\text { outcomes. Clinical medicine } \mathcal{E} \quad \text { research, 12(1-2), } & \text { 47-57. }\end{array}$ https://doi.org/10.3121/cmr.2014.1201 
14. Qureshi, S. A., Ahern, T., O'Shea, R., Hatch, L., \& Henderson, S. O. (2012). A standardized code blue team eliminates variable survival from in-hospital cardiac arrest. The Journal of emergency medicine,42(1), 74-78. https://doi.org/10.1016/j.jemermed.2010.10.023

15. Ryzner, D. M., \& Kujath, A. S. (2018). Low-Fidelity Code Blue Simulation on the Orthopaedic Unit. Orthopaedic Nursing, 37(4), 230-234. https://doi.org/10.1097/NOR.0000000000000475

16. Spitzer, C. R., Evans, K., Buehler, J., Ali, N. A., \& Besecker, B. Y. (2019). Code blue pit crew model: A novel approach to in-hospital cardiac arrest resuscitation. Resuscitation, 143,

158-164.. https://doi.org/10.1016/j.resuscitation.2019.06.290

17. Subhan, N., Giwangkencana, G. W., Prihartono, M. A., \& Tavianto, D. (2019). Implementasi Early Warning Score pada Kejadian Henti Jantung di Ruang Perawatan Rumah Sakit Dr. Hasan Sadikin Bandung yang Ditangani Tim Code Blue Selama Tahun 2017. Jurnal Anestesi Perioperatif, 7(1), 33-41.

18. Topple, M., Ryan, B., Baldwin, I., McKay, R., Blythe, D., Rogan, J., ... \& Jones, D. (2016). Tasks completed by nursing members of a teaching hospital Medical Emergency Team. Intensive and Critical Care Nursing, 32, 12-19. https://doi.org/10.1016/j.iccn.2015.08.008

19. Wehbe-Janek, H., Lenzmeier, C. R., Ogden, P. E., Lambden, M. P., Sanford, P., Herrick, J., ... \& Colbert, C. Y. (2012). Nurses' perceptions of simulation-based interprofessional training program for rapid response and code blue events. Journal of nursing care quality, 27(1), 43-50.

20. Wiliastuti, U. N., Anna, A., \& Mirwanti, R. (2018). Pengetahuan Tim Reaksi Cepat Tentang Bantuan Hidup Dasar.Jurnal Keperawatan Komprehensif (Comprehensive Nursing Journal), 4(2), 77-85. 